\title{
Original paper \\ Detrital chromian spinels from Miocene and Holocene sediments of northern Iraq: provenance implications
}

\author{
Ali I. AL-JUBOURY1*, Mohsin M. GHAZAL², Tom MCCANN \\ ${ }^{1}$ Research Center for Dams \& Water Resources, Mosul University, 58001, Mosul, Iraq; alialjubory@yahoo.com \\ ${ }^{2}$ Geology Department, College of Science, Mosul University, Iraq \\ ${ }^{3}$ Geological Institute, Bonn University, Nussallee 8, D-53115 Bonn, Germany \\ ${ }^{*}$ Corresponding author
}

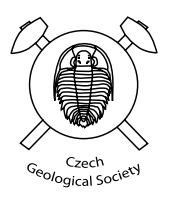

\begin{abstract}
The study integrates mineralogical and chemical characteristics of the chromian spinels from northern Iraq using standard petrographic and scanning microscope techniques as well as electron microprobe analyses in order to better understand their provenance, and the implications thereof. Detrital chromian spinels are found as one of the predominant accessory heavy minerals within fluviatile Miocene and Holocene sediments. In addition, such spinels are also present in the Palaeogene-Neogene and Cretaceous alluvial, deltaic and turbiditic sandstones. The results indicate that most of the chromian spinels have interrelated ranges of $\mathrm{Cr} /(\mathrm{Cr}+\mathrm{Al})$ at rather low contents of $\mathrm{Fe}$ and Ti suggesting that the sandstones which host the chromian spinels were derived from a source area dominated by ultramafic rocks. Mineralogical and chemical data suggest that Alpine-type peridotites were the main source rocks for the studied chromian spinels. All available evidence supports the idea that the sandstones originated from the ophiolite-radiolarite belt of the Taurus Range in northeastern Turkey, as well as from recycling of the uplifted Cretaceous strata of northern Iraq.
\end{abstract}

Keywords: chemistry, provenance, detrital chromian spinel, northern Iraq

Received: 25 March 2007; accepted: 26 May 2009; handling editor: J. Sejkora

\section{Introduction}

The minerals of the spinel group show extensive solid solution between the various end-member compositions. The chemistry of the spinel group minerals is expressed as $\mathrm{AB}_{2} \mathrm{O}_{4}$, where $\mathrm{A}$ represents divalent cations $\left(\mathrm{R}^{2+}\right)$ and $\mathrm{B}$ trivalent cations $\left(\mathrm{R}^{3+}\right)$. The group can be subdivided, according to the trivalent ion present, into the spinel (Al), magnetite $\left(\mathrm{Fe}^{3+}\right)$ and chromite series $(\mathrm{Cr})$. Deer et al. (1992) have noted that the mineral is relatively sensitive to the source chemistry and temperature resulting in a wide compositional range of the chromian spinel in divalent $\left(\mathrm{Mg}^{2+}\right.$ and $\left.\mathrm{Fe}^{2+}\right)$ and trivalent $\left(\mathrm{Al}^{3+}, \mathrm{Cr}^{3+}\right.$ and $\left.\mathrm{Fe}^{3+}\right)$ elements.

Chromian spinel $\left[\left(\mathrm{Fe}^{2+}, \mathrm{Mg}\right)\left(\mathrm{Cr}, \mathrm{Fe}^{3+}, \mathrm{Al}\right)_{2} \mathrm{O}_{4}\right]$, a member of the spinel group, is an accessory mineral found only in mafic and ultramafic rocks (accounting for $c$. 1-2 vol. \%). Among the heavy minerals in sediments and sedimentary rocks, detrital spinel group grains, and chromian spinels in particular, are unique in terms of their occurrence and geotectonic implications. They are considered to be a good provenance indicator of mafic and ultramafic rocks, especially of Alpine-type peridotites (Press 1986; Arai and Okada 1991; Cookenboo et al. 1997; Arai et al. 2006a, b; Uysal et al. 2007). Due to their chemical and mechanical resistance, spinels are enriched in sands and even placer deposits (Lee 1999). Chromian spinel can also be found in clastic sedimentary rocks, especially in sandstones and siltstones (Hisada et al. 2002).

The chemical composition of the detrital chromian spinels can potentially be used as a sensitive indicator of the host-rock tectonic setting or of physico-chemical conditions under which the host rock formed (Irvine 1965; Zimmerle 1984; Dick and Bullen 1984; Press 1986; Pober and Faupl 1988; Arai 1990; Hisada and Arai 1993; Lee 1999; Hisada et al. 2002).

In Iraq, chromian spinel, formerly referred to as chromite by many researchers lacking the access to the modern analytical facilities, is one of the most abundant opaque minerals recorded in the heavy mineral fractions of Holocene and older detrital deposits (Philip 1968; Jawad Ali and Khoshaba 1980; Al-Rawi 1980, 1981; Amin and Al-Juboury 1989; Al-Juboury 1994, 2001; AlJuboury et al. 1999; 2001a, b, c). In some localities from northern Iraq, the Holocene sediments are characterized by high contents of chromian spinel. In fact, iron oxides and chromian spinel account for c. $50 \%$ of the total heavy minerals, and the chromian spinel forms up to $80 \%$ of the opaque minerals of the Holocene sediments of the Tigris River and its tributaries in some areas of northern Iraq (Al-Juboury et al. 1999).

In the present contribution, we report on the occurrence, enrichment and provenance of detrital chromian spinel obtained from Miocene and Holocene sediments in 
northern Iraq and discuss the implications of its chemistry on the provenance and palaeogeography of the region.

\section{Geological background}

The study area extends from highly folded zone of the Foreland Basin into the foreland and related basins, as well as the platform region of the Arabian Plate (Fig. 1).
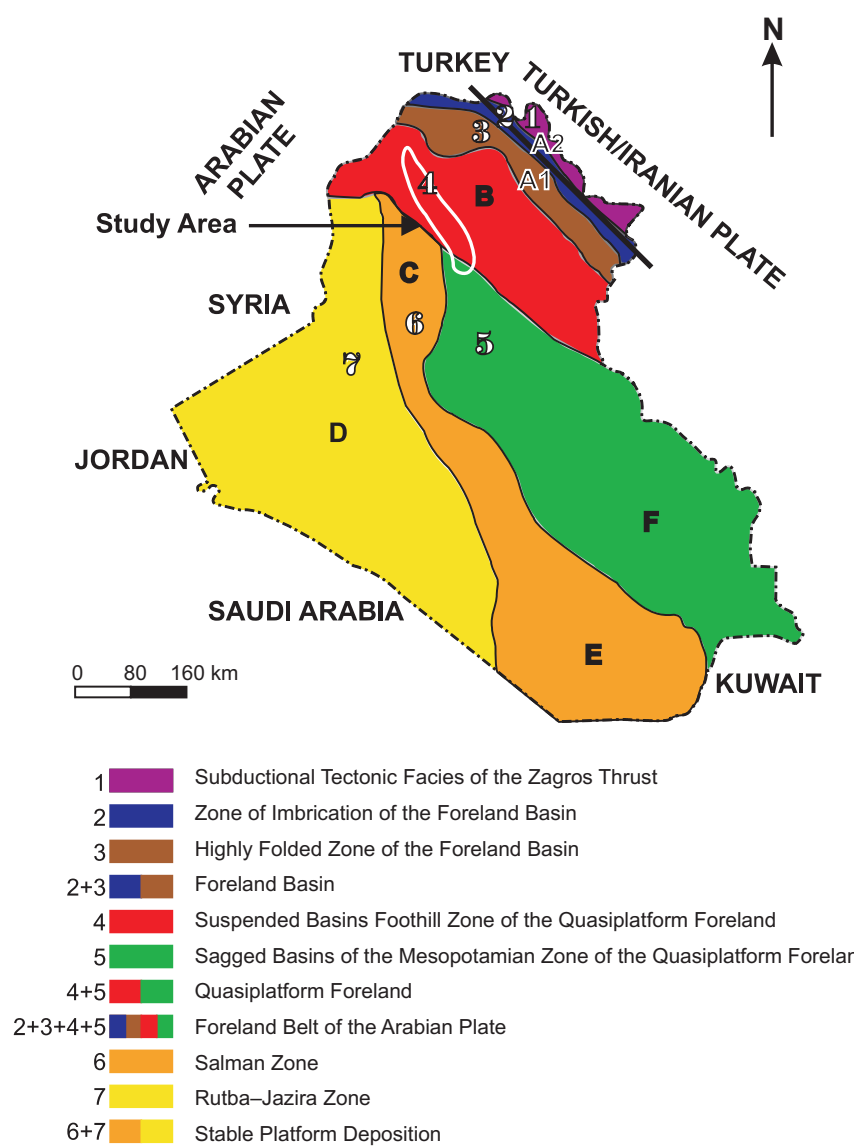

Fig. 1 Tectonic division (modified from Numan 2001) and the physiographic provinces of Iraq. Provinces are: Zagros Mountains (A1, folded zone; A2, nappe zone), Foothills (B), Jezira (C), Northern (D) and Southern (E) deserts and the Mesopotamian Plain (F) (after Berry et al. 1970).

This region extends along the Tigris River from Mosul Lake ( $\sim 50 \mathrm{~km}$ northwest of Mosul) passing through this city as far as Sharqat ( $110 \mathrm{~km}$ further south) (Fig. 2).

The Zagros Thrust Zone of northeastern Iraq consists of parallel ridges of folded Upper Paleozoic and Mesozoic limestones, and a nappe of metamorphosed Lower Paleozoic rocks present along the Iranian border (Figs 1, 3). The Foothill Zone consists mainly of Upper Miocene and Pliocene coarse detrital sediments which are gently folded along the NW-SE axis parallel to the structural trend of the Zagros Mountains. To the west is the Rutba-

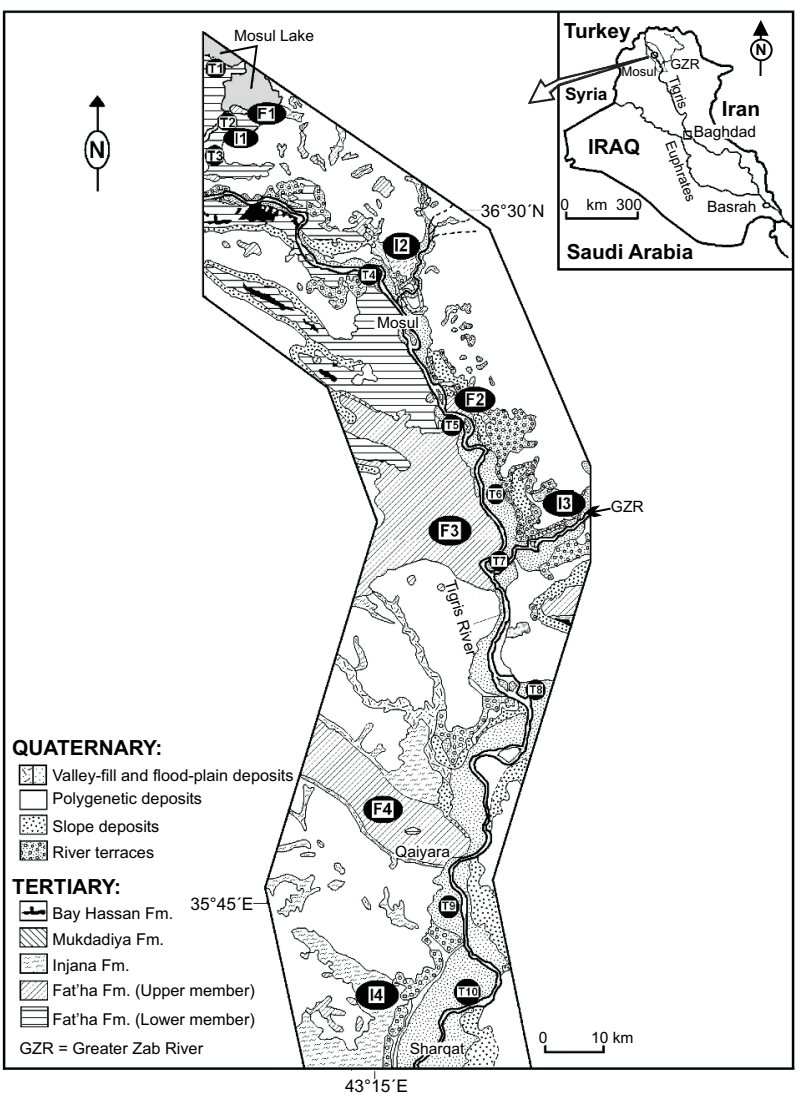

Fig. 2 Schematic geological map and surficial geology of the study area showing the Quaternary-Holocene and some of older formations along the Tigris River with sample locations. T - Tigris River samples (Holocene), F and I - samples from Fatha (Middle Miocene) and Injana (Upper Miocene) formations.

Jezira Zone, which consists of relatively undisturbed Miocene and Pliocene limestones and gypsum, as well as poorly consolidated Pleistocene detritus (Berry et al. 1970).

Iraq is located at the contact between the major Phanerozoic units of the Middle East, i.e. the Arabian part of the African Platform (Nubio-Arabian) and the Asian branches of the Alpine tectonic belt. The platform part of the Iraqi territory is divided into two main units, i.e., stable and unstable shelves. The stable shelf is characterised by a relatively thin sedimentary cover, which shows little evidence of significant folding. In contrast, the unstable shelf comprises a thick, folded sedimentary cover, where the intensity of the folding increases toward the northeast (Buday 1980; Jassim and Goff 2006). Structurally, the studied area lies in the Foothill and Mesopotamian zones of the platform foreland of Iraq as shown in Fig. 1 (Numan 2001).

In terms of its structural evolution, the region underwent a significant phase of deformation in Pliocene times, as part of the Alpine Orogeny. This resulted in the 
widespread deposition of more than $2.5 \mathrm{~km}$ of conglomerates in the Foreland Basin Basin (Mukdadiyah and Bai Hassan formations, formerly Lower and Upper Bakhtiari formations respectively, Al-Rawi et al. 1993). Extensive folding, basement fault rejuvenation and isostatically driven uplift occurred during this phase of deformation (Numan 1997). The continental collision between the underthrusted Arabian Plate and the overriding Turkish and Iranian plates caused the evolution of the unstable shelf and formation of a marginal basin. It also resulted in the creation of accommodation space for rapid sediment build up during the Miocene that led to the accumulation of significant sedimentary deposits in this area (Numan 1997) (Fig. 4).

\section{Materials and methods}

Seventy two samples were collected from 18 localities (4 from each locality, Fig. 2). The sampled intervals include the upper clastic unit of the Fatha Formation (Middle Miocene) and the Injana Formation (Upper Miocene) together with sands from the Tigris River (Holocene) in northern Iraq (Tab. 1). The petrographic analysis was carried out at the Geology Department, Mosul University, Iraq. Samples with relatively high percentages of chromian spinels were selected for electron probe microanalysis (EPMA). Sixty grains (24 of Miocene and 36 of Holocene sediments) were analysed in total, as shown in Tab. 2. The detrital chromian spinel grains were separated by standard separation methods (Hubert 1971). Three polished thin sections prepared from these detrital grains were analysed using the wavelength dispersive CAMEBAX microprobe at the Mineralogical Institute, Bonn University, Germany. Analytical error by this technique is less than 0.5 wt. $\%$ for major oxides and $<0.001$ wt. $\%$ for minor oxides.

The ZAF method was applied to raw intensity correction for each oxide. Various natural and synthetic minerals were used as

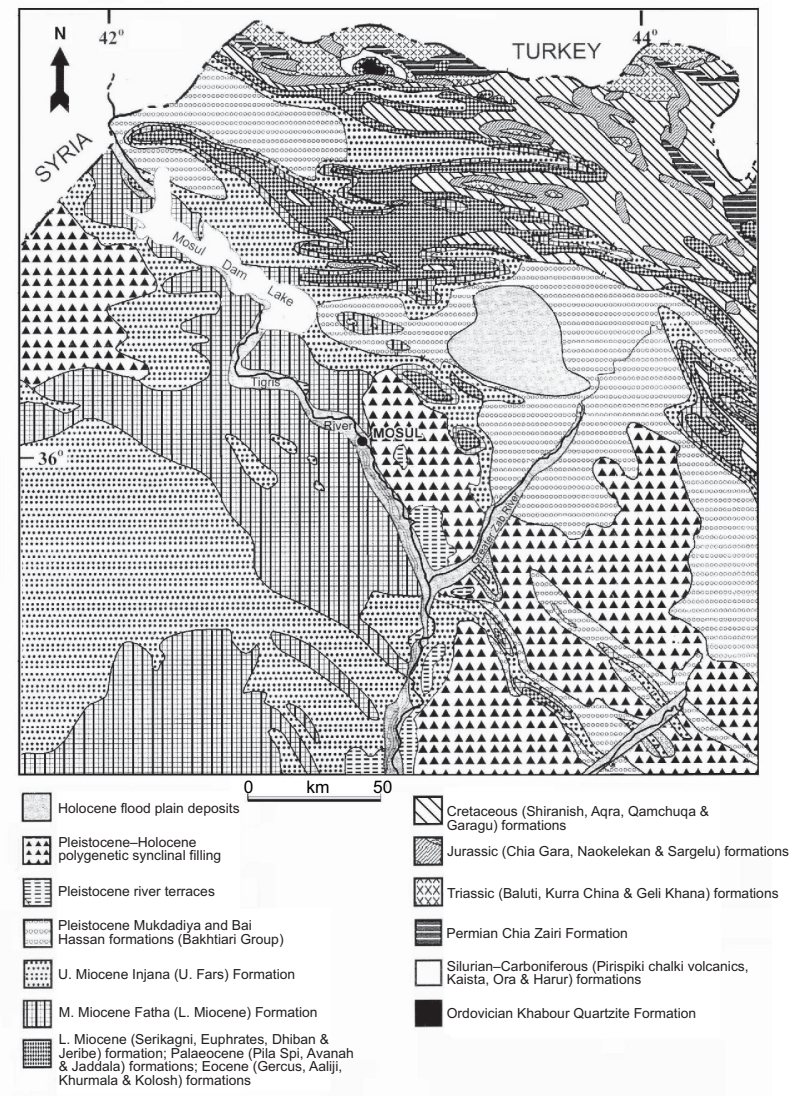

Fig. 3 Geological map of northern Iraq showing the Ordovician to Holocene formations (modified from the Geological map of Iraq 1986).

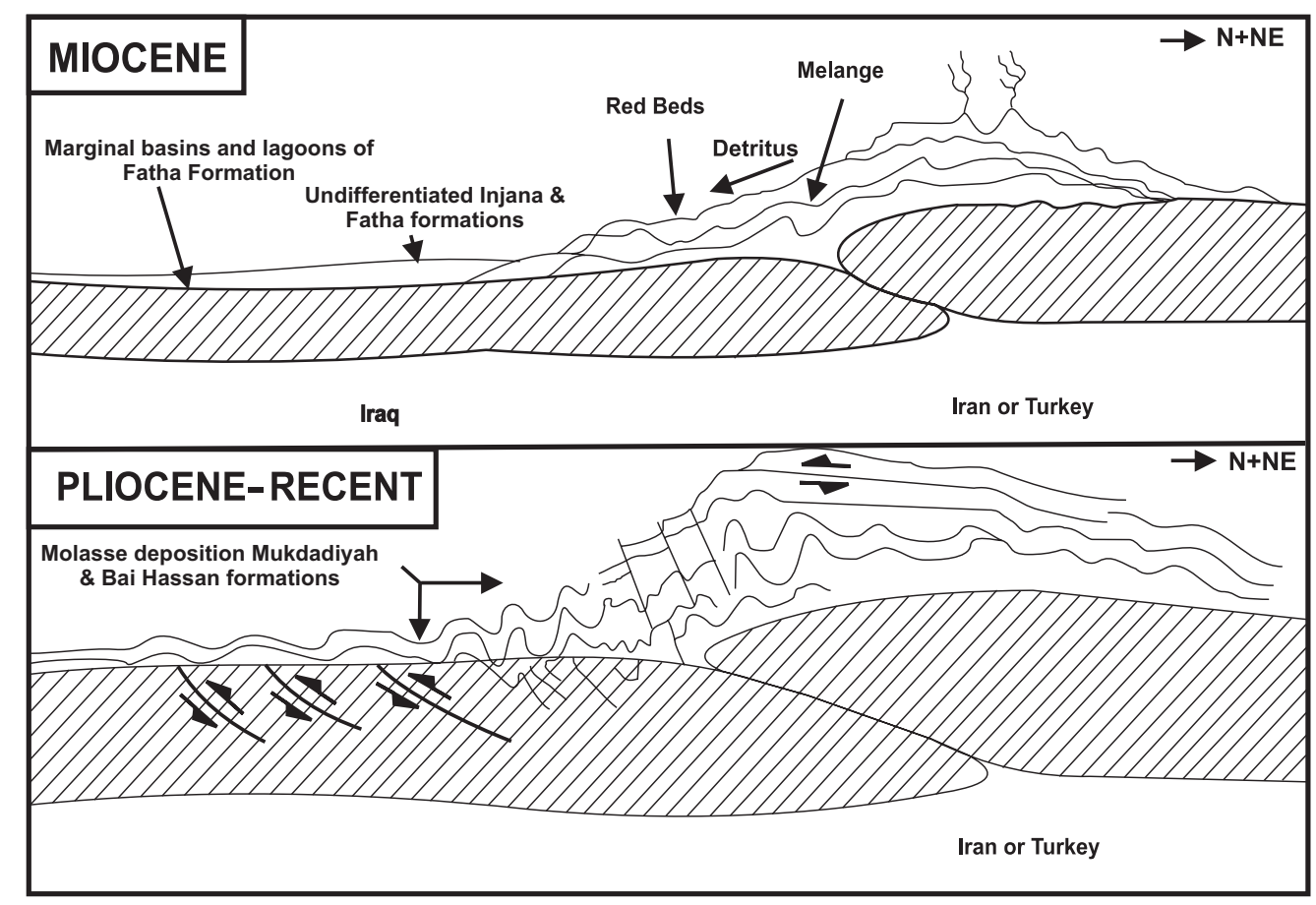

Fig. 4 The Phanerozoic plate tectonic models for northern Iraq and surrounding areas with the collisional set-up model for the Miocene and Pliocene-Holocene (from Numan 1997). 
standards for the calibration. The following analytical conditions were employed: $15 \mathrm{kV}$ accelerating voltage, $20 \mathrm{nA}$ beam current and $3 \mu \mathrm{m}$ beam diameter on $\mathrm{MgO}$ (periclase). The counting time was $20 \mathrm{~s}$ on the peak and $10 \mathrm{~s}$ on the background.

Scanning Electron Microscope (SEM) observations were carried out using CamScan MV 2300 at the Paleontological Institute, Bonn University, Germany. Five analyses of each grain were made, one in the centre and others near the rim. No significant differences were found and the grains thus can be considered to be homogeneous. No obvious changes were recorded in the amount of $\mathrm{Fe}^{3+}$ close to the observed etched pits of the grains.

\section{Petrography}

Detrital chromian spinels in the Miocene samples were generally recorded from sandstones which are classified as sub-arkoses and sub-litharenites. Additionally, most of these sandstones are carbonate rich. In contrast, the Holocene sands are mainly fine-grained and were classi- fied as litharenites comprising various amounts of quartz, feldspars, mica, and sedimentary rock fragments.

The heavy mineral assemblages observed in the samples taken from the Holocene and the older Miocene deposits contained nearly the same minerals but in varying proportions. Most of the observed minerals fall into one of five groups: opaque, epidote, garnet, amphibole and pyroxene. These represent more than $80 \%$ of the heavy minerals in the majority of samples studied. Opaque minerals generally form more than $50 \%$ of the heavy fraction and are predominantly composed of chromian spinels, which can comprise up to two thirds of the studied opaque minerals in some localities of northern Iraq (Al-Juboury et al. 1999) along with magnetite, ilmenite, pyrite and hematite.

Table 1 displays the percentages of the heavy minerals in the studied samples. Reference is given to the enrichment some of them in detrital chromian spinels (and chromite). Marked are also the samples selected for chemical analyses.

Detrital chromian spinels were most abundant in fine to very fine grained sandstones. In transmitted light, the

Tab. 1 Average relative percentages (mean of 4 samples from each locality) of the heavy minerals

Tigris River sediments

\begin{tabular}{|c|c|c|c|c|c|c|c|c|c|c|c|c|c|c|c|c|c|c|}
\hline \multirow{2}{*}{ Locality } & \multirow{2}{*}{ Opq } & \multirow{2}{*}{$\begin{array}{c}\mathrm{Cr} \\
\mathrm{Spl}\end{array}$} & \multirow{2}{*}{ Amp } & \multirow{2}{*}{$P x$} & \multirow{2}{*}{ Ep } & \multirow{2}{*}{ Grt } & \multicolumn{3}{|c|}{ Mica } & \multirow{2}{*}{ Zrn } & \multirow{2}{*}{ Tur } & \multirow{2}{*}{ Rt } & \multirow{2}{*}{ Ky } & \multirow{2}{*}{$\mathrm{St}$} & \multirow{2}{*}{ Spl } & \multirow{2}{*}{ Spn } & \multirow{2}{*}{ Ap } & \multirow{2}{*}{$\mathrm{Ol}$} \\
\hline & & & & & & & Ms & $\mathrm{Bt}$ & Chl & & & & & & & & & \\
\hline T1 Sehaila & 31.2 & 37 & 4.8 & 6.1 & 9.4 & 6.3 & 16.2 & 10.1 & 13.2 & 0.7 & 1.0 & 0.4 & 0.4 & 0.1 & - & - & - & - \\
\hline T2 Wana* & 38.3 & 44 & 3.9 & 6.2 & 18.4 & 3.5 & 11.2 & 5.3 & 10.1 & 1.0 & 1.2 & 0.1 & 1.2 & 0.1 & 0.1 & 0.1 & 0.1 & - \\
\hline T3 Badosh & 35.5 & 40 & 4.4 & 5.8 & 18.1 & 5.7 & 13.1 & 5.8 & 9.8 & 0.5 & 0.7 & - & 0.5 & 0.2 & - & - & - & - \\
\hline T4 Rashidiya* & 33.7 & 34 & 2.3 & 2.6 & 12.7 & 2.4 & 18.0 & 10.5 & 15.8 & 0.3 & 0.4 & - & 0.4 & - & - & - & - & - \\
\hline T5 Hamam Al-Alil & 46.4 & 54 & 4.3 & 5.1 & 18.6 & 10.0 & 8.3 & 1.4 & 2.7 & 0.7 & 0.9 & 0.2 & 0.6 & - & - & - & - & 0.2 \\
\hline T6 Makhlat-1* & 50.1 & 56 & 2.9 & 4.8 & 17.2 & 13.2 & 6.4 & 1.7 & 3.2 & 0.3 & 0.6 & 0.1 & - & - & 0.2 & - & 0.1 & - \\
\hline T7 Makhlat-2* & 54.1 & 60 & 2.7 & 7.4 & 22.1 & 2.2 & 5.4 & 0.7 & 3.0 & 0.5 & 0.9 & - & - & - & - & - & - & - \\
\hline T8 Qayara* & 52.3 & 58 & 3.0 & 7.6 & 24.2 & 3.9 & 5.1 & 0.4 & 1.9 & 0.3 & 0.8 & - & - & - & - & 0.2 & - & 0.2 \\
\hline T9 Jirnaf & 52.1 & 60 & 2.8 & 6.8 & 25.1 & 6.8 & 3.4 & 1.1 & 0.3 & 0.6 & 0.9 & 0.5 & 0.7 & 0.1 & - & - & - & - \\
\hline T10 Sharqat* & 50.8 & 45 & 2.5 & 6.0 & 25.7 & 7.5 & 3.8 & 1.0 & 0.4 & 0.6 & 0.8 & - & 0.4 & - & 0.1 & - & - & - \\
\hline
\end{tabular}

\section{Miocene sediments}

\begin{tabular}{|c|c|c|c|c|c|c|c|c|c|c|c|c|c|c|c|c|c|c|}
\hline \multirow{2}{*}{ Locality } & \multirow{2}{*}{ Opq } & \multirow{2}{*}{$\begin{array}{c}\mathrm{Cr} \\
\mathrm{Spl}\end{array}$} & \multirow{2}{*}{ Amp } & \multirow{2}{*}{$\mathrm{Px}$} & \multirow{2}{*}{ Ep } & \multirow{2}{*}{ Grt } & \multicolumn{3}{|c|}{ Mica } & \multirow{2}{*}{ Zrn } & \multirow{2}{*}{ Tur } & \multirow{2}{*}{ Rt } & \multirow{2}{*}{$\mathrm{Ky}$} & \multirow{2}{*}{ St } & \multirow{2}{*}{ Spn } & \multirow{2}{*}{ Ap } & \multirow{2}{*}{ Cld } & \multirow{2}{*}{$\mathrm{Ol}$} \\
\hline & & & & & & & Ms & $\mathrm{Bt}$ & Chl & & & & & & & & & \\
\hline I1 Dao Al-Qamr & 38.7 & 35 & 5.3 & 2.0 & 44.0 & 2.1 & 0.2 & 1.1 & 0.2 & 3.2 & 0.3 & 0.4 & 0.2 & 0.3 & - & 0.2 & 0.8 & - \\
\hline I2 Wadi Al-Malah * & 56.4 & 45 & 12.2 & 3.5 & 11.6 & 8.7 & - & 1.8 & 1.0 & 1.7 & 1.2 & 0.8 & - & - & - & - & - & - \\
\hline I3 Namrud & 68.5 & 40 & 4.9 & 4.0 & 8.2 & 4.2 & - & - & 1.0 & 3.1 & 2.5 & 1.5 & 0.7 & 1.5 & - & - & - & - \\
\hline I4 Sharqat* & 49.5 & 55 & 9.1 & 7.3 & 15.1 & 5.1 & - & - & 0.3 & 4.0 & 3.5 & 2.2 & - & - & - & - & 0.5 & - \\
\hline F1 Butmah & 50.3 & 50 & 1.1 & 3.4 & 17.5 & 6.2 & 1.1 & 0.7 & 1.5 & 5.8 & 1.0 & 8.2 & 0.2 & 1.2 & 0.1 & - & - & - \\
\hline F2 Salamiya* & 51.5 & 42 & 1.0 & 3.0 & 22.7 & 4.3 & 0.9 & 0.7 & 2.9 & 5.0 & 0.9 & 6.1 & 0.1 & 1.2 & - & - & - & - \\
\hline F3 Hamam Al-Alil* & 52.5 & 45 & 0.8 & 2.6 & 23.5 & 5.4 & - & 0.5 & 3.5 & 4.8 & 1.3 & 4.5 & - & 1.1 & - & - & - & - \\
\hline F4 Shoura & 56.5 & 54 & 1.3 & 1.9 & 20.0 & 4.3 & - & 0.4 & 2.2 & 5.9 & 1.5 & 3.9 & - & 0.7 & - & 0.1 & - & - \\
\hline
\end{tabular}

Abbreviations: Amp - Amphibole; Ap - Apatite; Bt - Biotite; Chl - Chlorite; Cld - Chloritoid; Cr Spl - Chromian spinel; Ep - Epidote; Grt Garnet; Ky - Kyanite; Ms - Muscovite; Ol - Olivine; Opq - Opaque; Px - Pyroxene; Rt - Rutile; Spl - Spinel; Spn - Sphene; St - Staurolite; Tur - Tourmaline; Zrn - Zircon (Kretz 1981)

Stars refer to the localities, from which samples were chosen for chemical analysis, see Fig. 2 for sample locations. 
chromian spinel grains are generally fresh and their shape ranges from angular to subrounded. The mineral is very opaque and appears as smooth, brilliant and jet-black to deep brown in colour, especially the abraded grains, possibly indicating their wide $\mathrm{Cr}-\mathrm{Al}-\mathrm{Fe}^{3+}$ substitution with a pronounced conchoidal fracture for the broken ones (Fig. 5a). This may relate to leaching during transportation of $\mathrm{Cr}$ and its substitution by $\mathrm{Al}$ and $\mathrm{Fe}$ at these weak surfaces. This process applies especially for the Holocene chromian spinels.

Scanning electron microscope photomicrographs (Figs 5b-f) show euhedral chromian detrital grains with evidence of dissolution, and the presence of grooves as well as indicators of corrosion on their surface suggesting a high degree of chemical weathering in the depositional environment. Chromian spinel is generally resistant to low-grade alteration and mechanical breakdown. The observed conchoidal fractures are thought to have been formed as a result of mechanical weathering (Fig. 5b).

The surface textures observed on the chromian spinels indicate the combined effects of mechanical attrition and chemical etching during the transport of the mineral grains within the flow of the river as well as any possible effects prior to transportation in the river.

\section{Mineral chemistry}

The results of the EPMA analysis of the detrital chromian spinels are presented in Tab. 2. Total $\mathrm{Fe}$ was measured as ferrous iron oxide $\left(\mathrm{FeO}_{\mathrm{t}}\right)$. The calculation of ferrous $\left(\mathrm{Fe}^{2+}\right)$ and ferric $\left(\mathrm{Fe}^{3+}\right)$ ions are from raw analyses assuming spinel stoichiometry. The parameters $\mathrm{Mg} \#, \mathrm{Cr} \#$ and $\mathrm{Fe}^{3+} \#$ are defined as $\mathrm{Mg} /\left(\mathrm{Mg}+\mathrm{Fe}^{2+}\right), \mathrm{Cr} /(\mathrm{Cr}+\mathrm{Al})$, and $\mathrm{Fe}^{3+} /$ $\left(\mathrm{Cr}+\mathrm{Al}+\mathrm{Fe}^{3+}\right)$, respectively.

The analyzed detrital chromian spinels in all samples correspond to magnesiochromite since they have high $\mathrm{Cr}$ contents (1.135-1.336 apfu) and relatively low and slightly variable $\mathrm{TiO}_{2}$ contents $(0.01$ to 0.27 wt. \%; Tab. 2). The chromian spinels show higher $\mathrm{TiO}_{2}$ in the Holocene (average $=0.121$ wt. \%) than in the Miocene (average $=0.033$ wt. \%) sediments.

The $\mathrm{Mg} \#$ values range from 0.511 to 0.659 . The chromian spinels present in the Miocene sediments have higher $\mathrm{Cr} \#$ values (average $=0.648$ ) than those in the Holocene sediments (average $=0.610$ ). In addition, the $\mathrm{Mg} \#$ of spinels from Miocene sediments (average = 0.595 ) is higher than of those present in the Holocene sediments (average $=0.539$ ).

Generally, the studied chromian spinels of the Holocene sediments have relatively higher $\mathrm{Al}$ values (Al $=0.727-0.818 \mathrm{apfu}$; average $=0.756 \mathrm{apfu})$ than those measured in the Miocene samples $(\mathrm{Al}=0.687-0.746$ apfu; average $=0.708 \mathrm{apfu})($ Tab. 2) .

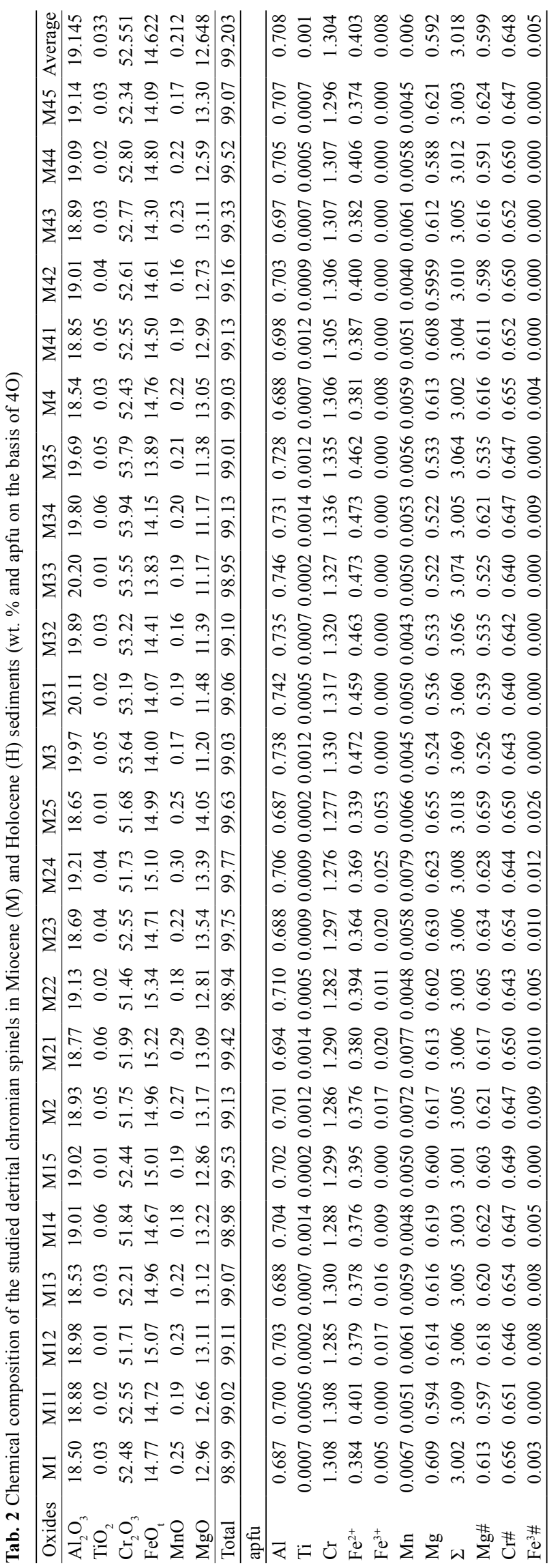



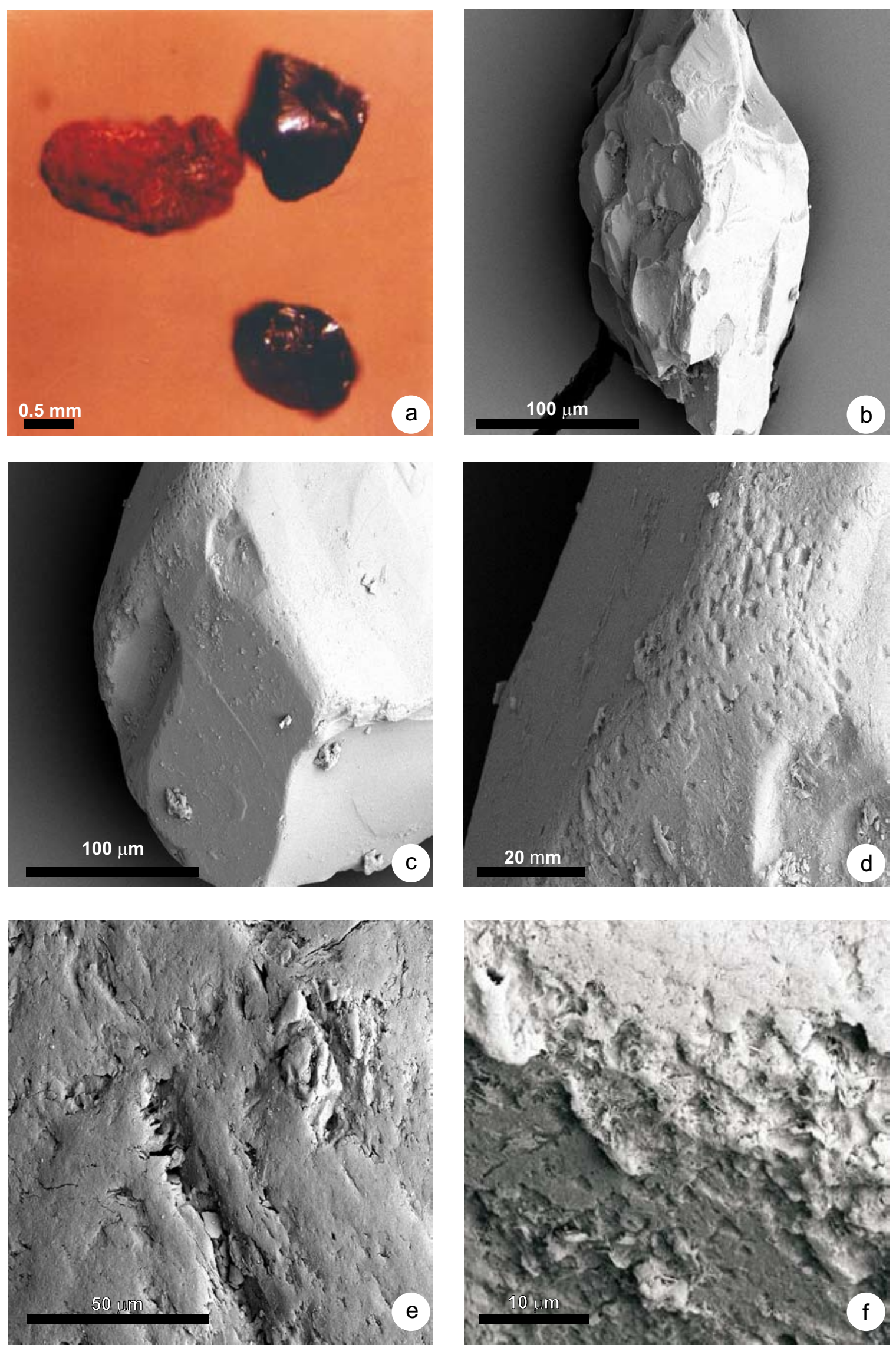
Tab. 2 (Continued)

\begin{tabular}{|c|c|c|c|c|c|c|c|c|c|c|c|c|c|c|c|c|c|c|}
\hline Oxides & H1 & 11 & 12 & 13 & H14 & H15 & $\mathrm{H} 2$ & $\mathrm{H} 21$ & $\mathrm{H} 22$ & $\mathrm{H} 23$ & 124 & 125 & 13 & 1 & 132 & 33 & 34 & H35 \\
\hline $\mathrm{Al}_{2} \mathrm{O}_{3}$ & 19.06 & .18 & .12 & 0.01 & 0.40 & 9.25 & 9.12 & 9.21 & 9.24 & 19.15 & 19.31 & 19.29 & 19.13 & 9.18 & 9.23 & 9.30 & 9.22 & 9.29 \\
\hline $\mathrm{CiO}_{2}$ & 0.19 & .15 & .18 & 0.09 & 0.20 & 0.21 & 0.17 & 0.16 & 0.19 & 0.20 & 0.17 & 0.15 & 0.16 & 0.18 & 0.19 & 0.21 & 0.21 & 0.27 \\
\hline $\mathrm{Cr}_{2} \mathrm{O}_{3}$ & 45.37 & 46.10 & 5.71 & 5.99 & 45.55 & 45.85 & 45.51 & 45.61 & 45.71 & 45.33 & 45.53 & 45.89 & 44.70 & 44.95 & 44.81 & 44.44 & 45.05 & 44.88 \\
\hline $\mathrm{eO}_{\mathrm{t}}$ & 22.29 & 22.31 & 22.36 & 21.11 & 22.14 & 22.07 & 22.43 & 22.37 & 22.61 & 22.18 & 22.54 & 22.13 & 22.77 & 22.69 & 22.52 & 22.75 & 23.01 & 22.73 \\
\hline $\mathrm{AnO}$ & 0.26 & 0.30 & 0.22 & 0.28 & 0.26 & 0.23 & 0.24 & 0.21 & 0.20 & 0.25 & 0.22 & 0.22 & 0.21 & 0.20 & 0.24 & 0.21 & 0.18 & 0.23 \\
\hline $\mathrm{MgO}$ & 10.39 & 10.56 & 1.07 & 11.23 & 10.37 & 10.66 & 11.43 & 11.49 & 11.39 & 11.46 & 11.57 & 11.57 & 11.63 & 11.55 & 11.64 & 11.74 & 1.46 & 11.70 \\
\hline otal & 97.56 & 3.60 & .66 & 3.71 & 8.92 & 98.27 & 8.90 & 9.05 & 9.34 & 98.57 & 9.34 & 9.25 & 98.60 & 75 & 8.63 & 8.65 & .13 & 99.10 \\
\hline \multicolumn{19}{|l|}{ apfu } \\
\hline 1 & 36 & 732 & & 757 & 772 & 736 & & 29 & 28 & .729 & .730 & .729 & 9 & 30 & .732 & .735 & 30 & .731 \\
\hline$\Gamma \mathrm{i}$ & 0.0047 & 0.0037 & 0.0044 & 0.0022 & 0.0048 & 0.0051 & 0.0041 & 0.0039 & 0.0046 & .0049 & 0.0041 & 0.0036 & 0039 & 0044 & 0.0046 & 0.0051 & 0051 & 0065 \\
\hline $\mathrm{Cr}$ & 1.175 & 1.181 & 1.169 & 1.167 & 1.156 & 1.176 & 1.160 & 1.160 & 1.160 & 1.158 & 1.155 & 1.164 & 1.143 & 1.148 & 1.145 & 1.135 & 147 & 1.141 \\
\hline $\mathrm{e}^{2+}$ & 0.486 & 0.482 & 0.460 & 0.455 & 0.497 & 0.478 & 0.444 & 0.443 & 0.449 & 0.441 & 0.441 & 0.441 & 0.433 & 0.438 & 0.433 & 0.429 & 0.445 & 0.433 \\
\hline $\mathrm{e}^{3+}$ & 0.125 & 0.123 & 0.145 & 0.111 & 0.098 & 0.121 & 0.161 & 0.159 & 0.158 & 0.159 & 0.164 & 0.153 & 0.183 & 0.174 & 0.176 & 0.186 & 0.175 & 0.179 \\
\hline Mn & 0.0072 & 0.0082 & 0.0060 & 0.0076 & 0.0071 & 0.0063 & 0.0066 & 0.0057 & 0.0054 & 0.0068 & 0.0060 & 0.0060 & 0.0058 & 0.0055 & 0.0066 & 0.0057 & 0049 & .0063 \\
\hline $\mathrm{Mg}$ & 0.507 & 0.510 & 0.534 & 0.537 & 0.496 & 0.516 & 0.550 & 0.551 & 0.545 & 0.552 & 0.553 & 0.553 & 0.561 & 0.556 & 0.561 & 0.565 & 0.550 & 0.561 \\
\hline 5 & 3.040 & 3.040 & 3.047 & 3.036 & 3.031 & 3.039 & 3.052 & 3.052 & 3.051 & 3.051 & 3.053 & 3.050 & 3.060 & 3.057 & 3.057 & 3.060 & 3.052 & 3.057 \\
\hline Mg\# & 0.511 & 0.514 & 537 & 0.541 & 0.500 & 0.519 & 0.553 & 0.554 & 0.548 & 0.556 & 0.557 & 0.557 & 0.564 & 0.559 & 0.564 & 0.569 & 0.553 & 0.564 \\
\hline $\mathrm{r} \#$ & 0.615 & 0.617 & 616 & 0.607 & 0.600 & 0.615 & 0.615 & 0.614 & 0.614 & 0.614 & 0.613 & 0.615 & 0.611 & 0.611 & 0.610 & 0.607 & 0.615 & 0.609 \\
\hline${ }^{3} \#$ & 061 & 50 & 1 & 55 & 048 & 059 & 9 & 078 & .077 & .077 & 30 & .075 & 9 & 85 & .086 & .090 & 079 & 0.087 \\
\hline xide & H4 & & & & & 45 & $\mathrm{H}$ & & & 54 & & $\mathrm{H}$ & & & 3 & & 65 & $a g$ \\
\hline${ }_{2} \mathrm{O}_{3}$ & 68 & 72 & 55 & 86 & 77 & 201 & .14 & 20 & .27 & 20.90 & 20.70 & 20.01 & 20 & .09 & 0.71 & 0.67 & 0.12 & 20.07 \\
\hline $\mathrm{O}_{2}$ & 0 & 0 & & $0^{2}+2$ & 09 & 0.11 & 08 & 07 & 10 & 0 & 09 & 02 & 03 & .04 & .01 & .06 & 8 & .121 \\
\hline${ }_{2} \mathrm{O}_{3}$ & 46.84 & 88 & 66 & 17 & 27 & 14 & 4 & 37 & 82 & 10 & 22 & 28 & 50 & 29 & .51 & .44 & 48 & 6.828 \\
\hline $\mathrm{O}_{\mathrm{t}}$ & 1 & 17.94 & 17.75 & 01 & 17.99 & 17.66 & 18.19 & 18.40 & 8 & 9 & 4 & 1 & 5 & 12 & 06 & .29 & 11 & 251 \\
\hline $\mathrm{nO}$ & 0.24 & 25 & & 25 & 0.26 & 0.23 & & 0.24 & 6 & 6 & 0.23 & 27 & 5 & 29 & 32 & 24 & 26 & .244 \\
\hline $\mathrm{gO}$ & 11.00 & 20 & 0 & 11.24 & .11 & 11.33 & 1 & 33 & .11 & 11.01 & .13 & 10.98 & .03 & .11 & 1.22 & 38 & 99 & 11.229 \\
\hline tal & 64 & 03 & 98.07 & 56 & 49 & 48 & 99.31 & 61 & 54 & 21 & 61 & .87 & 56 & 24 & 8.83 & .08 & 4 & 98.74 \\
\hline \multicolumn{19}{|l|}{ apfu } \\
\hline & 15 & 13 & & 14 & 11 & 18 & 0 & 51 & 53 & 777 & 0.768 & 757 & 759 & 757 & .773 & 770 & 59 & 0.756 \\
\hline & 0010 & 0.0010 & 0.0012 & 0.0007 & 0.0021 & 0.0026 & 0.00 & $.001^{\prime}$ & 0.0024 & 0.0012 & 0.0021 & 0.0005 & 0.0007 & 0.0010 & 0.0002 & 0014 & 19 & 0.003 \\
\hline $\mathrm{n} r$ & 1.181 & 1.177 & 1.169 & 1.178 & 1.182 & 1.175 & 1.234 & 1.231 & 1.242 & 1.224 & 1.224 & 1.226 & 1.223 & .221 & 1.215 & .211 & 226 & 1.184 \\
\hline $2^{2+}$ & 471 & 0.463 & 0.440 & 0.464 & 0.469 & 0.461 & 0.461 & 0.461 & 0.471 & 0.475 & 0.472 & 0.467 & 0.469 & .462 & 462 & .457 & 69 & 0.458 \\
\hline $3+$ & 0.005 & 0.013 & 0.030 & 0.012 & 0.006 & 0.005 & 0.020 & 0.024 & 0.003 & 0.000 & 0.008 & 025 & 0.026 & .030 & .017 & .026 & 019 & 0.084 \\
\hline In & 206 & 0.0 & 0.0 & $67-2$ & 0.0070 & 0.0061 & 0.0 & 0.0064 & 0 & 00060 & 00061 & 007 & $0 \Omega$ & 00079 & 00086 & 00064 & 70 & 0.007 \\
\hline $\mathrm{Mg}$ & 0 & 0 & 0 & 0 & 0 & 0 & 0 & 0 & 22 & 18 & 22 & 26 & 24 & 30 & 530 & 36 & 524 & 535 \\
\hline & 3 & 3 & 3 & 3 & 3 & 3 . & 3 & 3 & 0 & 2 & 2 & 08 & 08 & 10 & 06 & 08 & 06 & \\
\hline g\# & 6 & 4 & & 0 & 7 & 0 & 0 & 36 & 26 & 21 & 25 & 29 & 28 & 34 & 34 & 40 & 28 & 539 \\
\hline+4 & 0.592 & 0.591 & 0.591 & 0.591 & 0.593 & 0.590 & 0.622 & 0.621 & 0.622 & 0.612 & 0.615 & 0.618 & 0.617 & 0.617 & 0.611 & 0.611 & 8 & 0.610 \\
\hline$e^{3} \#$ & .002 & 0.007 & 0.015 & 0.006 & 0.003 & 0.002 & 0.010 & 0.012 & 0.002 & 0.000 & 0.004 & 0.012 & 0.013 & 0.015 & 0.008 & 0.013 & 0.009 & 0.04 \\
\hline
\end{tabular}

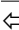

Fig. 5a - photomicrograph of brilliant black to deep brown detrital chromian spinel and brown hematite from Holocene sediments, northern Iraq; b-f Scanning Electron Microscope (SEM) micrographs of detrital chromian spinels from Holocene sediments of Tigris River, northern Iraq: $\mathbf{b}$ - chromian spinel with conchoidal fracture from Miocene sandstones; $\mathbf{c}$ - euhedral chromian spinels from Holocene sandy sediments of Tigris River showing few sub-rounded grooves; $\mathbf{d}$ - enlarged view of (c) showing several dissolution pits; $\mathbf{e}$ - elongated grooves with evidence for dissolution of chromian spinels; $\mathbf{f}$ - highly corroded surfaces of chromian spinels from Holocene Tigris River sand.
The $\mathrm{Fe}^{3+}$ content is consistently low, mostly below $0.06 \mathrm{apfu}$. The average is $0.008 \mathrm{apfu}$ for the Miocene sediments, i.e. lower than for the Holocene sediments (0.048 apfu). The $\mathrm{MnO}$ contents are $0.16-0.30$ wt. \% in the chromian spinels of the Miocene strata (average 0.212 wt. \%), and $0.18-0.32$ wt. \% in the Holocene sediments (average 0.244 wt. \%). 


\section{Discussion}

\subsection{Occurrences of detrital chromian spinels}

The Holocene sandy sediments along the Tigris River and the older sedimentary rocks from northern Iraq contain similar heavy mineral suites but with variations in the proportions of individual minerals. However, it is clear that the source rocks for both the recent sediments and the older successions have remained the same since Middle Miocene times. The heavy mineral assemblage is dominated by opaque minerals (mainly chromian spinel) as well as epidote, pyroxene, amphibole, garnet, zircon, tourmaline, rutile, kyanite, staurolite, olivine, sphene, apatite, biotite, muscovite and chlorite, all of which were apparently derived from metamorphic and, to a lesser extent, igneous sources.

The angular to subrounded shape of the studied chromian spinel grains indicates that the transport distance, subsequent to the weathering of the source rocks, was relatively short. Detrital chromian spinels from Miocene and Holocene clastics in northern Iraq were generally deposited in fluvial systems, including the upper clastic unit of the Fatha Formation (Middle Miocene), Injana Formation (Upper Miocene), Mukdadiya and Bai Hassan formations (Pliocene), Quaternary Tigris River terraces and Holocene sands from the Tigris River (Fig. 2). Chromian spinel was also recorded in older sedimentary units as noted by Al-Rawi (1981) for the Cretaceous Tanjero clastics, Amin and Al-Juboury (1989) for the Kolosh Formation (Palaeocene-Lower Eocene) and by Al-Rawi (1980) for the Gercus Formation (Eocene).

The depositional environments of these chromian spinel-bearing sedimentary successions range from turbiditic interdigitating with both shallow marine and deltaic environments for the Tanjero and Kolosh formations to alluvial, deltaic and shallow marine sediments for the Gercus Formation. The studied sediments from the upper unit of the Fatha Formation include sandstones (mainly carbonate rich) and siltstones which were deposited in a bird's foot, fluvial-dominated delta system (Al-Juboury et al. 2001a; Al-Juboury and McCann 2008). On the other hand, the studied sandstones from the Injana Formation were deposited in a fluviatile environment partly affected by wave processes (Al-Juboury 1994). The Mukdadiya and Bai Hassan clastics represent typical post-orogenic molasse (i.e. continental) sedimentation. These sediments were derived from the rapid erosion of the uplifted Taurus-Zagros Mountains and their deposition in fluviatile and lacustrine environments in foothill troughs (Kukal and Al-Jassim 1971).

The development of a series of fluvial terraces reflected the cyclic climatic changes which occurred in Pleistocene times. During the early Pleistocene, the catchment area of the River Tigris was subjected to extension-related erosion, which resulted in the production of enormous amounts of sediments, all of which were transported into the main river channel. The resultant choking of the channel by the poorly sorted sediments led to the formation of a series of longitudinal coarse-grained gravel-rich bars and islands (Al-Juboury et al. 2001b).

The Holocene sediments of the Tigris River consist mainly of loose to fairly well-indurated deposits of sands, silts and mud. There are minor deposits of pebbles in some upstream areas and these are mostly of local origin, eroded from the adjacent sedimentary formations (AlJuboury et al. 2001c).

\subsection{Factors controlling the enrichment of chromian spinels in sediments}

Several ideas have been published concerning the accumulation of heavy minerals in fluvial and stream sediments. Wolf (1981) suggested that the gravity is the most important segregating mechanism accounting for the close association of small, dense grains with lighter but larger mineral grains in sediments. Additional controlling factors include the density and hardness of the minerals, the difference in the original size of the grains in the source rocks, the degree of abrasion during transportation and the degree of sorting at the site of deposition. In contrast, Rittenhouse (1943) attributed the distribution of heavy minerals in stream beds to varying hydraulic conditions at the time and place of deposition, the equivalent hydraulic size of each of the heavy minerals and the availability of the minerals.

In the present study, the content of heavy minerals in the $0.25-0.063 \mathrm{~mm}$ fraction generally exceeds $1 \%$. The chromian spinels are enriched in the finer fraction $0.063 \mathrm{~mm}(4 \varnothing)$ (very fine sand) rather than in the medium sand $0.25 \mathrm{~mm}(2 \varnothing)$. Such enrichment may relate to several factors (Al-Juboury et al. 1999), for example, the source area that supplies the weathered chromian spinel grains, the recycling of the minerals from the older clastics (mainly the Eocene Gercus Formation that contains more than $60 \%$ chromian spinel and chromite among the opaque heavy minerals as documented by Al-Rawi 1980), the low velocity of the Tigris River particularly in the study area, the hydraulic nature of the river and stream waters, and the high specific gravity of the chromian spinel and chromite.

\subsection{Provenance implications}

The $\mathrm{Cr} \#$ and $\mathrm{Mg} \#$ are the most characteristic parameters employed in classification and nomenclature of chromian spinels. Moreover, these, together with the major- $\left(\mathrm{Cr}_{2} \mathrm{O}_{3}\right.$ and $\mathrm{MgO}$ ) and minor-element oxides (especially $\mathrm{TiO}_{2}$ and $\mathrm{Fe}_{2} \mathrm{O}_{3}$ ) are very useful as provenance indicators. 
Palaeocurrent direction for the clastics in northern Iraq was measured by Al-Rawi (1980), who concluded that they were derived from the ophiolitic Taurus complexes in NE Turkey. Thus analytical data for ten fresh (unaltered) chromian spinels from the Kop Mountains (Taurus) - the presumed source of detrital chromian spinels of the present study - were used for comparison (Uysal et al. 2007).

The Cr\#-Mg\# plot (Fig. 6) indicates that the detrital chromian spinels of the present study are of the magnesiochromite type, which is similar to the Taurus chromian spinels from NE Turkey. The magnesiochromite is characterized by having both $\mathrm{Cr} \#$ and $\mathrm{Mg} \#$ values of more than 0.5 .

The relatively high content of $\mathrm{Cr}_{2} \mathrm{O}_{3}$, when plotted against $\mathrm{TiO}_{2}$ (Fig. 7a), shows that the studied detrital

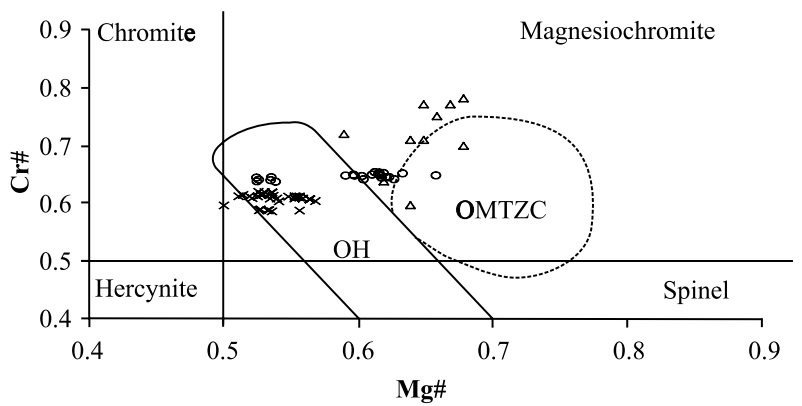

Fig. 6. The Cr\# versus Mg\# plot showing the classification and nomenclature of the Miocene (open circles) and Holocene (crosses) chromian spinels of the present study compared with those from Taurus, NE Turkey (Uysal et al. 2007; open triangles, $\mathrm{n}=10$ chromian spinels). It illustrates also their probable provenance. $\mathrm{OH}=$ Oman chromian spinels in harzburgites (Le Mée et al. 2004); OMTZC $=$ Oman Moho Transition Zone chromian spinels in chromitites (Augé 1987; Ahmed and Arai 2002).

chromian spinels, similarly to the chromian spinels from Kop Mountains, are of podiform type, not stratiform, due to lower content of $\mathrm{TiO}_{2}(<0.3$ wt. \%). A similar interpretation can be derived from Fig. $7 \mathrm{~b}$ based on the high content of $\mathrm{Al}_{2} \mathrm{O}_{3}$ when plotted against $\mathrm{Cr}_{2} \mathrm{O}_{3}$. On the other hand, the studied chromian spinels seem to belong to the Alpine-type peridotite type when the trivalent ions $\left(\mathrm{Cr}^{3+}, \mathrm{Fe}^{3+}\right.$ and $\left.\mathrm{Al}^{3+}\right)$ are displayed in the triangular plot (Fig. 8) as they contain low $\mathrm{Fe}^{3+}$ contents $(0-10 \%$ of total trivalent ions in the figure). The stratiform type spinels should have higher $\mathrm{Fe}^{3+}$ and the Alaskan-type spinels may have much higher $\mathrm{Fe}^{3+}$.

Furthermore, the plot of $\mathrm{Cr} \#$ vs. $\mathrm{TiO}_{2}$ for the chromian spinels of the present study is shown in Fig. 7. They are chemically similar to detrital chromian spinels from Oman (ODCS) (see also Arai et al. 2006a). On the other hand, in Fig. 6, they resemble Oman chromian spinels in harzburgite (Le Mée et al. 2004) rather than Oman
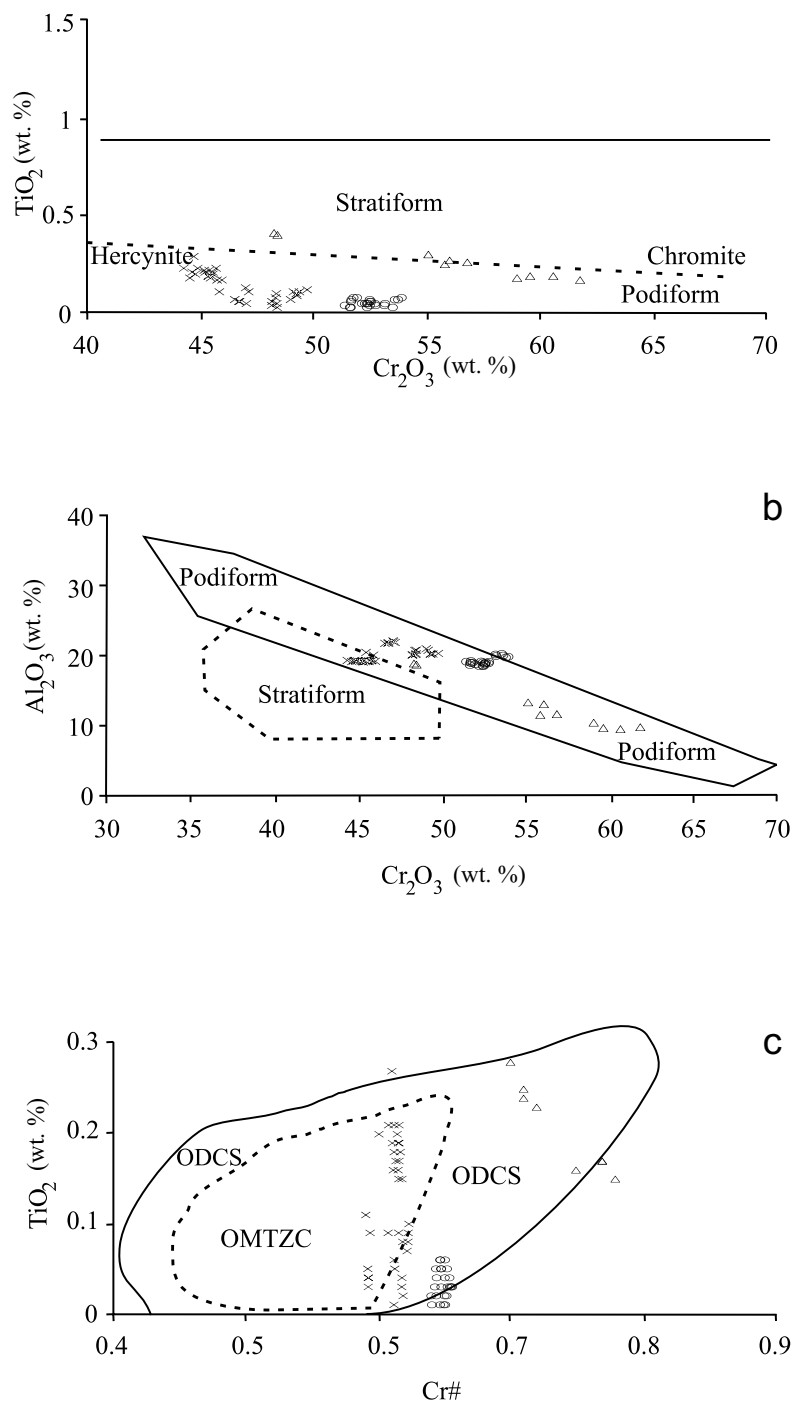

Fig. 7 Chemistry of the Miocene and Holocene chromian spinels of the present study and their comparison with spinels from Taurus (Uysal et al. 2007). $\mathbf{a}-\mathrm{Cr}_{2} \mathrm{O}_{3}$ versus $\mathrm{TiO}_{2}$ (wt. \%) plot; $\mathbf{b}-\mathrm{Cr}_{2} \mathrm{O}_{3}$ versus $\mathrm{Al}_{2} \mathrm{O}_{3}$ (wt. \%) plot; $\mathbf{c}$ - relationship between $\mathrm{Cr} \#$ and $\mathrm{TiO}_{2}$. "Podiform" and "stratiform" fields are from Mussallam et al. (1981). ODCS = Oman detrital chromian spinels that are representative of mantle-derived rocks of Oman ophiolite (Arai et al. 2006a). Symbols as in Fig. 6.

Moho transition zone chromites (Augé 1987; Ahmed and Arai 2002).

Generally speaking, the low $\mathrm{TiO}_{2}$ (lower than 0.2 wt. \%) for the Miocene chromian spinels (Tab. 2) suggest a peridotitic source rock, whereas $\mathrm{TiO}_{2}>0.2$ wt. \% for the Holocene chromian spinels may indicate a volcanic source (Kamenetsky et al. 2001).

Chromian spinels in northern Turkey occur as inclusions in peridotite, serpentine and metasomatites and are generally hosted by harzburgites and enveloped by thick dunitic sheathes (Güner 1979). Moreover, Uysal et al. (2007) suggested that the chromian spinels in the 


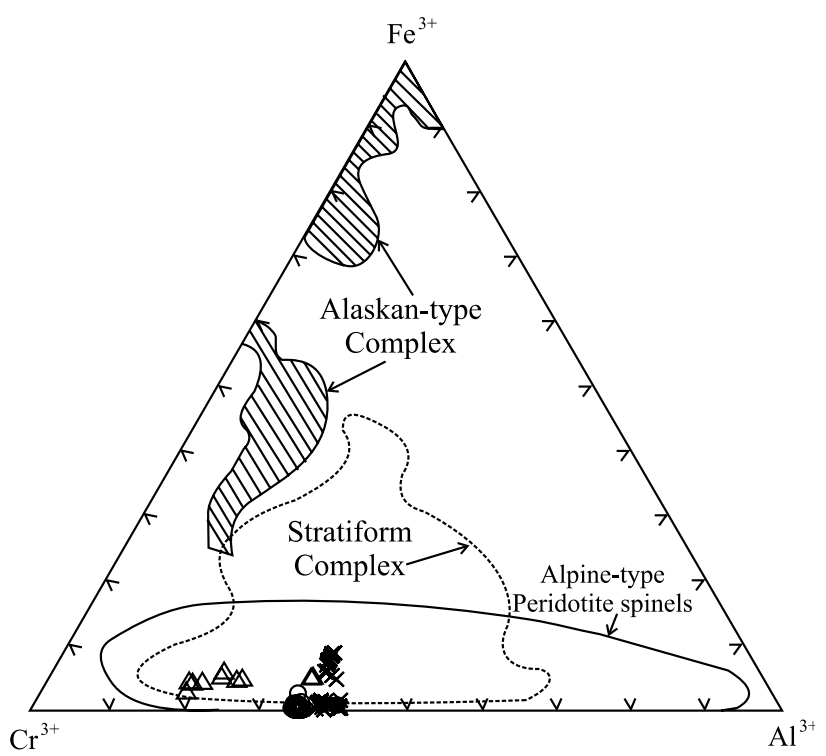

Fig. 8: Triangular plot of trivalent atoms $\mathrm{Cr}^{3+}-\mathrm{Fe}^{3+}-\mathrm{Al}^{3+}$ for the detrital chromian spinels of the present study and from Taurus (Uysal et al. 2007). The fields of Alpine-type peridotite, stratiform and Alaskan-type complexes are from Cookenboo et al. (1997). Symbols as in Fig. 6.

Kop Mountains in northeastern Turkey crystallized from a hydrous melt, enriched in $\mathrm{Na}$ and $\mathrm{K}$, which formed as the result of a low degree of partial melting in upper mantle or by peridotite-melt interaction, probably in a supra-subduction setting.

The presence of common angular forms of the studied chromian spinel particles indicates that transport distances were not too long. Immature chemical weathering of the ophiolites under highly oxidizing and alternating wet/dry conditions may have resulted in a unique composition of the weathering products from which a suite of heavy minerals, dominated by chromian spinel particles, was flushed away during periods of increased humidity. Then they were deposited in various local environments along a nearby elongated basin which included deltaic, floodplain alluvial fan and even shallow marine environments (Dhannoun and Al-Dabbagh 1990).

\section{Conclusions}

1. Detrital chromian spinels from the Holocene Tigris River and the older Miocene clastics of northern Iraq are commonly present in fine and very fine sands and sandstones. The grains are generally fresh, angular to subrounded and opaque with smooth brilliant and jet black to dark brown in colour.

2. Several surface textures were commonly found on the detrital grains including conchoidal fracture, evidence of dissolution, grooves, and corrosion on their borders.
These may have resulted from the combined effects of mechanical attrition and chemical etching during the transport.

3. The high $\mathrm{Cr}$ contents (1.13-1.34 apfu), relatively low $\mathrm{TiO}_{2}\left(0.01-0.27\right.$ wt. \%), and low $\mathrm{Fe}^{+3}$ contents (0-0.19 apfu) indicate that the detrital chromian spinels from the Miocene and Holocene clastics of northern Iraq are similar to those of the presumed source rocks in the Taurus Mountains, NE Turkey. They are derived from Alpine-type peridotites, serpentinized peridotites-chromitites or harzburgites.

4. The $\mathrm{Cr} \#-\mathrm{Mg} \#$ plot also indicates that the studied detrital chromian spinels are magnesiochromite, similar to both the Taurus "ophiolitic podiform" chromian spinels due to their lower content of $\mathrm{TiO}_{2}(<0.3 \mathrm{wt} . \%)$, and higher content of $\mathrm{Cr}_{2} \mathrm{O}_{3}\left(54>\mathrm{Cr}_{2} \mathrm{O}_{3}>44\right.$ wt. \%) when displayed against $\mathrm{Al}_{2} \mathrm{O}_{3}$.

Acknowledgements We would like to thank the Deutsche Akademische Austauschdienst (DAAD) for funding a two-month research visit at Bonn University for the senior author. Furthermore, we would like to thank the Geological Institute, Bonn University for providing access to their facilities. In particular we would like to thank Georg Oleschinski for scanning electron microscopy analysis. Thanks are due to Mineralogical Institute for microprobe analysis especially B. Spiering and A. Behr. Thanks are due to the reviewers; L. Gordon Medaris, Jr., Renata Čopjaková and Davide Lenaz for their fruitful comments and discussion.

\section{References}

Ahmed AH, Arai S (2002) Unexpected high-PGE chromitite from the deeper mantle section of the northern Oman ophiolite and its tectonic implications. Contrib Mineral Petrol 143: 263-278

Al-Juboury AI (1994) Petrology and provenance of the Upper Fars Formation (Upper Miocene), Northern Iraq. Acta Geol Uni Comen Bratislava 50: 45-53

Al-Juboury AI (2001) Paleogeography and provenance of Injana Formation, Iraq: based on petrography and heavy minerals distribution. Iraqi J Earth Sci 1: 36-51

Al-Juboury AI, McCAnn T (2008) The Middle Miocene Fatha (Lower Fars) Formation, Iraq. GeoArabia 13: 141-174

Al-Juboury AI, Ismail SA, Ghazal MM (1999) Chromite enrichment in the Recent fluviatile sediments, North Iraq. Qatar Uni Sci J 28: 159-167.

Al-Juboury AI, Al-Naqib SQ, Al-Juboury AM (2001a) Sedimentology and mineralogy of the Upper clastic units of Fat'ha Formation, South of Mosul, Iraq. Dirasat (Pure Sciences) Jordan 28: 80-106 
Al-Juboury AI, Ghazal MM, Al-Naqib SQ (2001b) Development and heavy minerals of the Tigris River terraces, North Iraq. Dirasat (Pure Sciences) Jordan 28: 245-259

Al-Juboury AI, Al-Miamary FA, Ghazal MM (2001c) Heavy minerals distribution of the Recent sandy deposits of Tigris River and its tributaries, North Iraq. Rafidain J Sci 12: 145-161

Al-Rawi Y (1980) Petrology and sedimentology of the Gercus Red Beds Formation (Eocene), Northeastern Iraq. Iraqi J Sci 21: 132-188

AL-Rawi IK (1981) Sedimentology and petrology of the Tanjero clastic Formation in north and northeastern Iraq. Unpublished Ph.D. thesis, Baghdad University, pp 1-295

Al-Rawi YT, Sayyab AS, Jassim Ja, Tamar-Agha M, Al-Sammarai AI, Karim SA, Basi MA, Hagopian D, Hassan KM, Al-Mubarak M, Al-Badri A, Dhiab SH, FARIS FM, ANWAR F (1993) New names for some of the Middle Miocene-Pliocene formations of Iraq (Fatha, Injana, Mukdadiya and Bai Hassan formations). Iraqi Geol J 25: 1-18

Amin MA, Al-Juboury AI (1989) Mineralogy and geochemistry of Tertiary-Cretaceous turbiditic sandstones, Shaqlawa, NE Iraq, Zanco 2: 106-122

ARAI S (1990) Chemical compositions of chromian spinel and olivine in some alkaline rocks from Japan. Sci Rep Kanazawa Uni 35: 25-38

ARAI S, OKada H (1991) Petrology of serpentine sandstone as a key to tectonic development of serpentine belts. Tectonophysics 195: 65-81

Arai S, Kadoshima K, Morishita T (2006a) Widespread arc-related melting in the mantle section of the northern Oman ophiolite as inferred from detrital chromian spinels. J Geol Soc, London 163: 869-879

Arai S, Shimizu Y, Ismail SA, Ahmed AH (2006b) Low-T formation of high-Cr spinel with apparently primary chemical characteristics within podiform chromitite from Rayat, northeastern Iraq. Mineral Mag 70: 499-508

Augé T (1987) Chromite deposits in the northern Oman ophiolite: mineralogical constraints. Miner Depos 22: $1-10$

Berry RW, Brophy GP, Naqash A (1970) Mineralogy of the suspended sediments in the Tigris, Euphrates and Shatt Al-arab rivers of Iraq and the recent history of the Mesopotamian plain. J Sed Petrol 40: 131-139

BuDAY T (1980) The Regional Geology of Iraq. Stratigraphy and Palaeo-geography. State Organization for Minerals, Baghdad, Iraq, pp 1-445

Cookenboo HO, Bustin RM, Wilks KR (1997) Detrital chromian spinel compositions used to reconstruct the tectonic setting of provenance: implications for orogeny in the Canadian Cordillera. J Sed Res 67: 116-123

Deer WA, Howie RA, Zussman J (1992). An Introduction to the Rock-Forming Minerals, $2^{\text {nd }}$ edition. Longman Scientific \& Technical, Hong Kong, pp 1-528

Dhannoun HY, Al-Dabbagh SMA (1990) The distribution of the $\mathrm{Fe}, \mathrm{Mn}, \mathrm{Ni}, \mathrm{Cr}$ and $\mathrm{Co}$ between the acid-soluble and Fe-oxides and hydroxides and matrix fractions of the Gercus Red Beds of northeast Iraq. Chem Geol 82: $57-68$

Dick HJB, Bullen T (1984) Chromian spinel as a petrogenetic indicator in abyssal and alpine-type peridotites and spatially associated lavas. Contrib Mineral Petrol 86: 54-76

Geological Map of Iraq (1986) Series scale 1:1000 000. Directorate General of Geological Survey and Mineral Investigation, Baghdad, Iraq

GÜNER M (1979) A note on chromo spinels and ore minerals from the Kure area, northern Turkey. Bull Min Res Explor Inst Turkey 92: 75-81

Hisada K, Arai S (1993) Detrital chromian spinel in the Cretaceous Sanchu sandstones, central Japan: indicator of serpentinite protrusion into a fore-arc region. Palaeogeogr Palaeoclimatol Palaeoecol 105: 95-109

Hisada K, Bunyoungkul Th, Charusiri P (2002) Detrital chromian spinels in Devonian-Carboniferous sandstones of Hikoroichi area, NE Japan: their provenance and tectonic relationship. Science Report Institute of Geoscience University of Tsukuba, Sec. B 23: 39-51

HUBERT JF (1971) Analysis of heavy mineral assemblages. In: Carver PE (ed) Procedures in Sedimentary Petrology, John Wiley \& Sons, New York, pp 453-478

IRVINE TN (1965) Chromian spinel as a petrogenetic indicator: part 1 - theory. Can J Earth Sci 2: 648-674

JASsim SZ, Goff JC (2006) Geology of Iraq. $1^{\text {st }}$ edition, Dolin. Prague and Moravian Museum, Brno, pp 1-345

Jawad Ali A, Khoshaba BN (1980) Petrography and heavy mineral studies of Lower Bakhtiari Formation. Iraqi Geol J 11:16-36

Kamenetsky VS, Crawford A.J, MefFre S (2001) Factors controlling chemistry of magmatic spinel: an empirical study of associated olivine, Cr-spinel and melt inclusions from primitive rocks. J Petrol 42: 655-671

KRETZ R (1981) Symbols for rock-forming minerals. Amer Miner 68: 277-279

Kukal Z, AL-Jassim J (1971) Sedimentology of Pliocene molasse sediments of the Mesopotamian geosyncline. Sed Geol 5: 57-81

LeE Y (1999) Geotectonic significance of detrital chromian spinel: a review. Geosciences J 3: 23-29

Le Mée L, Girardeau J, Monnier C (2004) Mantle segmentation along the Oman ophiolite fossil mid-ocean ridge. Nature 432: 167-172

Mussallam K, Jung D, Burgath K (1981) Textural features and chemical characteristics of chromites in ultramafic rocks, Chalkidiki Complex (Northeastern Greece). Mineral Petrol 29: 75-101 
Numan NMS (1997) A plate tectonic scenario for the Phanerozoic succession in Iraq. Iraqi Geol J 30: 85-110

Numan NMS (2001) Cretaceous and Tertiary Alpine subductional history in Northern Iraq. Iraqi J Earth Sci 1: 59-74

PhiLIP G (1968) Mineralogy of recent sediments of Tigris and Euphrates rivers and some of the older detrital deposits. J Sed Petrol 38: 35-44

Pober E, Faupl P (1988) The chemistry of detrital chromian spinels and its implications for the geodynamic evolution of the eastern Alps. Geol Rundsch 77: 641-670

PRESS S (1986) Detrital spinels from Alpinotype source rocks in Middle Devonian sediments of the Rhenish Massif. Geol Rundsch 75: 333-340
Rittenhouse G (1943) Transportation and deposition of heavy minerals. Geol Soc Am Bull 54: 1725-1780

Uysal I, Tarkian M, Sadikler MB, Sen C (2007) Platinumgroup-element geochemistry and mineralogy of ophiolitic chromitites from the Kop Mountains, Northeastern Turkey. Canad Mineral 45: 355-377

WoLF KH (1981) Handbook of Strata-bound and Stratiform Ore Deposits, 1. Principles and General Studies, Volume 3, Supergene and Surficial Ore Deposits, Textures and Fabrics. Elsevier, Amsterdam, pp 1-786

ZIMMERLE W (1984) The geotectonic significance of detrital brown spinel in sediments. Mitt Geol Paläont Inst Univ Hamburg 56: 337-360 